\title{
O pensamento das coisas em Francis Ponge e Georges Perec
}

Rodrigo Lelpo

Recebido em 24 mai 2012 - Aprovado em 20 set 2012

\section{Resumo}

Esse trabalho tem por objetivo analisar os processos de subjetivação por meio da escrita nas poéticas descritivas de Francis Ponge e Georges Perec. Ao descreverem a banalidade do mundo que os cerca, Ponge e Perec estabelecem uma relação entre as coisas, o homem e a linguagem através de uma economia narrativa em que quanto mais o sujeito descreve o espaço exterior, mais ele se aproxima de uma busca de si.

Palavras-chave: Francis Ponge; Georges Perec; subjetivação; poesia francesa contemporânea. 
1 Publicado dois anos antes da "Sociedade do espetáculo" de Guy Débord, o livro de Perec trata exatamente da relação apontada pelo filósofo em seu libelo contra a economia de mercado:

A primeira fase da dominação da economia sobre a vida social levou, na definição de toda a realização humana, a uma evidente degradação do ser em ter. A fase presente da ocupação total da vida social pela acumulação de resultados econômicos conduz a um deslocamento generalizado do ter ao parecer, de onde todo o «ter» efetivo deve retirar seu prestígio imediato e a sua função última. (DÉBORD, 1992, p.22)

A título de curiosidade, basta compararmos o texto de Débord com a seguinte passagem do livro de Perec, a qual remete, ao mesmo tempo, às "Mitologias" de Barthes:

L'Express lhes oferecia todos os signos do conforto: os grossos roupões de banho, as desmitificações brilhantes, as párias da moda, a culinária exótica, os objetos úteis, as análises inteligentes, o segredo dos deuses, os cantinhos baratos, as diferentes opiniões, as ideias novas, os vestidinhos em conta, os pratos congelados, os detalhes da elegância, os escândalos de bom-tom, os conselhos de último minuto. (PEREC, 2012, p.35)
Durante a Segunda Guerra Mundial, Francis Ponge publicou o seu O partido das coisas, livro cujo título aponta, de forma provocativa, para aquele que seria o traço determinante de sua poética. Anos depois, o jovem Georges Perec fazia sua entrada na cena literária francesa, em 1965, com a publicação do romance As coisas. A evidência dos títulos não desmente o paralelismo proposto nesse artigo, embora a primeira obra de Perec, escrita enquanto ele frequentava os cursos de Roland Barthes que viriam a constituir as reflexões expostas pelo crítico em suas Mitologias, não seja foco de nossa atenção. A despeito da referência às "coisas", o que encontramos em seu primeiro livro é, de certo modo, uma exposição crítica e ficcional do conceito marxista de fetiche. Essa relação indicada por Perec de maneira muito clara ao dizer que os protagonistas Jérôme e Sylvie "não têm outro desejo que não o que lhes é conferido pela publicidade... Eles não têm carne." (PEREC, 2003a, v.2, p.279) ${ }^{1}$.

O que pauta as reflexões empreendidas nesse artigo pode ser compreendido a partir de uma passagem proferida por Ponge em uma conferência na Alemanha, ao chamar a atenção do público para o fato de que "aqui os objetos também vivem. Eles estão por todo lado, estamos rodeados por testemunhas mudas (....." (PONGE, 1961, p.219) Essas testemunhas de que nos fala o poeta permitem ao escritor encenar o diálogo entre homens e coisas para além da relação com o mundo sob a forma da mercadoria, tal como aparece no primeiro romance de Perec. Ainda assim, é preciso dizer que, para além da indicação do título, a prática do inventariado sob a forma de listas e enumerações saturadas de objetos nos permite entrever o deslocamento na relação entre homens e coisas que irá aparecer em textos como Tentative d'épuisement d'un lieu parisien e em seu romance mais conhecido, $A$ Vida modo de usar. É aí que encontramos a relação que propomos estabelecer entre os dois escritores, a qual, inclusive, não passou despercebida a Perec.

Numa entrevista concedida a Gabriel Simony, o escritor compara seu procedimento descritivo com aquele utilizado por Ponge:

É um pouco como em Ponge (...). Quando se descreve, acaba-se sempre por dizer que não se vai até o final da descrição e, efetivamente, poder-se-ia continuar ainda mais longe, ir até os átomos. Mas como ir até os átomos? (PEREC, 2003a, v.2, p.212)

Encontramos outra pista interessante quanto a essa relação em Perec ou la cicatrice, de Jean Duvignaud. Nele, o autor nos fala 
de uma noite em que, Perec presente, Ponge recitava seu poema "A Terra":

Uma noite Ponge está lá, entre amigos, sentado sobre a cama, e seu porte imperial de Romano fascina. Num certo momento, simplesmente, como se conversássemos, ele lê um poema, "A Terra", que ele acaba de escrever...

\section{(...)}

É a reencarnação dos poetas da antiga Jônia, essa "raiva fria da expressão" que dá um rosto àquilo que nomeia? "É talvez contra uma tendência à ideologia pastosa que inventei meu partido." Sabemos disso: somos seus leitores - "Sim, o partido nasce na extremidade de uma filosofia da não-significação do mundo (e da infidelidade dos meios de expressão)." Um ato inaugural. "O partido das coisas." As coisas... Perec está à espreita. (DUVIGNAUD, 1993, p.24-25)

"À espreita" das coisas, "à espreita" de Ponge... Assim, apesar das diferenças entre seus trabalhos, podemos perceber um operador comum pautado por esse processo de nomeação das "coisas" que nos cercam. Falando do ato de nomear com Jean Royer, Perec explicita o seu ponto de vista sobre a questão:

Creio, então, que essa atividade de escrever repousa sobre essa espécie de necessidade perpétua em nomear, em designar, em descrever até que tenhamos o sentimento de que não poderemos mais descrever. Nossa relação com o mundo exterior consiste - como para uma criança - em aprender o nome de tal coisa. Na verdade, essa acumulação das palavras, não é exatamente para tentar ver o fim, mas ver a partir de quando pode nascer a idéia de vertigem nessa atividade. (PEREC, 2003a, v.2, p.78)

Na sequência dessa entrevista, o escritor relaciona o fragmento acima à "necessidade de conservar" que sentem as sociedades diante da perda que nos assombra. Todavia, é curioso notar que Perec, ao falar dessa atividade de nomeação que estaria na base da escritura - e da conservação do mundo - diz no final da passagem supracitada que o objetivo da acumulação das palavras estaria ligado à ideia de vertigem. Ainda na mesma entrevista, $\mathrm{o}$ escritor assinala a existência de "um tipo de burocracia da conserva, da colocação dos eventos em conserva." (idem, ibidem). Essa crítica - pois Perec acusa a inutilidade de tal burocracia - remete à aporia que se encontra na base do trabalho de nomeação. É preciso conservar, consequentemente, é preciso nomear, encontrar uma mise en forme para esse trabalho, uma organização que sustentaria os mecanismos de conservação. Mas para quê se, de acordo com o escritor, esses mecanismos não funcionam?

A partir dessa aparente aporia é que podemos tentar empreender uma interpretação da ideia de vertigem à qual Perec se refere. A vertigem seria a criação de mecanismos ficcionais que 
permitiriam ao escritor retirar as palavras de seu estado de "sono" para "acordar" o mundo aos olhos do leitor. Por essa via, ela marcaria a intromissão daquele que escreve através da manipulação da linguagem. Por meio dessa operação é que o mundo descrito pode sair de um agenciamento de signos que não faz mais do que servir à estabilidade da doxa para começar a existir. Por esta via, a representação da realidade encontraria sua maior potência através da intromissão do sujeito da escritura, afirmando assim a inscrição de uma subjetividade.

Ponge, na introdução do seu livro O partido das coisas, expõe um raciocínio que nos permite desenvolver essa questão: "[n]ão me conhecerão, não terão uma idéia de mim senão através da minha concha, de minha morada, de minhas coleções; ou antes, pois são armas, de minhas panóplias. Através do acento de minha representação do mundo." (PONGE, 2000, p.38) Ao dizer essas palavras, o poeta torna explícita as relações entre o sujeito que escreve e as imagens que ele cria por via de sua escritura, afastando todo purismo objetivo ao estabelecer uma relação direta entre "representação" e "acento". Dito de outra forma, de acordo com o poeta, cada coisa figurada por seu texto é, em alguma medida, reveladora daquele que o criou. As imagens de sua poesia seriam [in]formadas por uma escritura que, longe de capturar a verdade de um mundo-em-si, são testemunhos de um olhar. Esse acento, podemos pensá-lo como a resultante da contaminação daquele que escreve sob a forma do escrito, única maneira de trazer à luz a imagem das coisas que o poeta quer evocar.

Avançando este tipo de reflexão, pode-se dizer que as imagens fabricadas por Ponge e Perec são o resultado de uma dialética do olhar permitindo ao sujeito de se ver naquilo que ele descreve. Tal atitude pressupõe um real que é antes de tudo produção de um sujeito diante das coisas que os olham. Ou seja, ainda que não se possa reduzir o real a uma forma discursiva, é pelo / no discurso que podemos criar modelos de inteligibilidade que o possam figurar. Segundo Michel de Certeau, "a espessura e a extensão do 'real' não se designam, nem se lhes confere sentido senão em discurso (...)." (CERTEAU, 2002, p.37) E um discurso não existe senão a partir de um sujeito que coloca a língua em jogo.

A escritura torna-se, assim, a forma de uma experiência. Trata-se de um encontro, a imagem como a forma dessa afecção do escritor pela vida, o qual, através da palavra, afeta essa mesma vida em um constante movimento de ir e vir. No texto "De la modification des choses par la parole", publicado por Ponge em seu Proêmes, podemos ler a encenação desse movimento que ocasionará a própria modificação perceptiva que temos da coisa nomeada:

A uma, do mesmo modo, onda, a um conjunto informe que enche seu conteúdo, ou pelo menos que o esposa até certo nível 
2 No texto "Aproximações do quê?", pode-se ler uma passagem em que encontramos uma espécie de definição para o termo:

$\mathrm{O}$ que acontece realmente, o que vivemos, o resto, todo o resto, onde ele está? O que acontece a cada dia e que sempre retorna, o banal, o cotidiano, o evidente, o comum, o ordinário, o infra-ordinário, o ruído de fundo, o habitual, como dar conta disso, como interrogá-lo, como descrevê-lo? (PEREC, 2010, p.179)

3 Esse fragmento foi retirado da entrevista com Simony, mencionada no início do artigo. Logo após o comentário citado, Perec fala do trabalho do pintor italiano Gnoli, explicitando sua relação com a pintura hiper-realista e a imagética do sonho: “(...) a mudança de escala fazia com que se tornasse um objeto completamente da ordem do sonho." (op. cit., p.213) da forma, - pelo efeito da espera, de uma acomodação, de uma espécie de atenção de mesma natureza ainda, pode entrar o que ocasionará sua modificação: a palavra. (PONGE, 2006, p.122)

Poderíamos ter esse fragmento por uma parte de um pequeno tratado sobre as relações entre linguagem, mundo e sujeito. Aliás, o vocábulo parole, tal como figurado no poema, nos leva a pensar na clássica diferença entre langue e parole assinalada por Saussure, desenvolvida por Benveniste no artigo "Observações da função da linguagem na descoberta freudiana":

A língua fornece o instrumento de um discurso no qual a personalidade do sujeito se liberta e se cria, atinge o outro e se faz reconhecer por ele. Ora, a língua é uma estrutura socializada, que a palavra sujeita a fins individuais e intersubjetivos, juntando-lhe assim um perfil novo e estritamente pessoal. (BENVENISTE, v.1, 1995, p.84)

E esse "perfil novo", quem mais senão o escritor para aí explorar suas maiores consequências? Uma vez mais, trata-se do acento de que Ponge nos fala, e que no momento mesmo em que diz a coisa, a modifica, restituindo assim o lugar do sujeito que escreve no seio da imagem figurada.

Num diálogo com as reflexões do filósofo e historiador da arte Georges Didi-Huberman, pode-se dizer que para o tipo de escritura da qual tratamos, a forma se revelaria como sintoma. No capítulo "Question de détail, question de pan", do livro Devant l'image, Didi-Huberman explica da seguinte maneira o uso que faz do conceito freudiano no campo da arte, no caso em questão, no domínio do "visual":

O sintoma é um evento crítico, uma singularidade, uma intrusão, mas ele é ao mesmo tempo uma construção de uma estrutura significante, um sistema que o evento tem por responsabilidade de fazer surgir, mas parcialmente, contraditoriamente, de modo que o sentido não surja senão como enigma ou fenômeno-índice, não como conjunto estável de significações. (DIDI-HUBERMAN, 1990, p.307)

Com base nesta passagem de Didi-Huberman e atentando-se para o lugar do descritivo nas obras de Ponge e Perec, poderíamos pensá-lo como um construtor de imagens-sintomas? No caso de Perec, é nesse desafio que parte de seus textos parece se lançar por intermédio de sua abordagem descritiva daquilo que ele chamará em suas reflexões sobre o cotidiano de "infra-ordinário".2 Retomando o diálogo com a noção de vertigem, Perec nos explica que "é preciso, todavia, que a descrição continue até que ela seja tão precisa que se torne irreal" (...)." (PEREC, 2003, v.2, p.212-213), alcançando um estado de sonho. ${ }^{3}$

Em A Vida modo de usar, ao descrever a cave do personagem Bartleblooth no capítulo LXXII, "Porões, 3", o narrador nos informa que, 
há uns restos de carvão com um balde esmaltado em preto que lá ficou em cima, desses que têm uma alça de ferro com uma empunhadura de madeira no meio; uma bicicleta dependurada num gancho de açougue; engradados de garrafas agora vazio; e as quatro malas de suas viagens, quatro grandes baús recurvos, cobertos de lona alcatroada, com reforços de fasquias de madeira e com cantoneiras e guarnições de cobre, inteiramente forrados no interior com folhas de zinco, a fim de garantir impermeabilidade. (PEREC, 2009, p.414)

Composto de frases longas que nos obrigam a regular a respiração para que não fiquemos sem ar antes do fim, esse fragmento mostra as imagens através de um acúmulo de informações que dão um bom exemplo do que Perec chama de fazer delirar as imagens. Alterando as descrições usuais das coisas através desse espaço de saturação - e a falta de pontuação tem aí um papel crucial -, o escritor modifica a percepção que temos de cada objeto nomeado, instaurando o enigma indicado mais acima por Didi-Huberman.

Trata-se do movimento de "intrusão" de que nos fala o historiador, permitindo ao escritor desmontar "o sistema estável de significações" que guia nossa percepção. Tal movimento entre a coisa figurada e o artista é que nos autoriza a pensar num duplo aspecto do sintoma. Ao nomear os objetos da vida cotidiana, ao descrevê-los, Perec se inscreve, assim como Ponge, no seio das imagens descritas. Falar do mundo seria então a condição necessária para falar de si, e cada imagem fabricada pela escritura seria um sintoma apontando para os processos de subjetivação do sujeito que escreve.

No caso de Ponge, para pegar um exemplo entre tantos, podemos ler essa passagem do poema em prosa "Anotações para uma concha", do livro O partido das coisas:

Uma concha é uma coisa pequena; mas posso desmesurá-la, recolocando-a onde a encontro, pousada na vastidão da areia. Porque então, apanhando um punhado de areia, ficarei a observar o pouco que me resta na mão, depois que pelo interstício de meus dedos quase toda ela tiver escorrido. Observarei alguns grãos, depois cada grão, e nenhum desses grãos de areia, nesse momento, me parecerá mais uma coisa pequena; e, logo, a concha formal, essa casca de ostra ou essa "tiara bastarda" que é a voluta, ou a assim denominada "navalha", me impressionará como um enorme monumento, ao mesmo tempo colossal e precioso, algo como o templo de Angkor, Saint-Maclou, ou as Pirâmides, com uma significação bem mais estranha que esses mui incontestáveis produtos de homens. (PONGE, 2000, p.215)

Comparado ao fragmento de Perec, citado há pouco, ficam claras as diferenças de estratégias adotadas, embora a desestabilização das significações usuais se faça igualmente presente no texto do poeta. Se uma exploração excessiva de informações parece presente nos dois autores, no caso do Ponge, o foco recai sobre uma única coisa, como a percorrer uma imensa superfície, 
4 Ao falar das descobertas de Freud sobre o inconsciente e, consequentemente, da mudança do paradigma conceitual concernente ao status do sujeito, Rabaté comenta a falência de uma posição conceitual estritamente fenomenológica sobre a questão: “[o] Eu não se apreende no momento em que ele se diz. A consciência dessa crise, do fato de que o sujeito não pode apreender-se a si mesmo, consuma-se no fracasso da fenomenologia husserliana em fundar um novo cogito." (RABATÉ, 2004, p.63) evitando assim a exploração de uma profundidade promovida pela mise en abyme tão utilizada por Perec. Ou seja, a cada deslocamento que o poeta parece fazer, é à coisa inicial que ele volta - a concha -, "alargando" essa superfície aparentemente tão ínfima. E é aqui que talvez apareça a estratégia mais eficiente nesse processo de desestabilização significativa, e que se deixa perceber logo na primeira frase pelo uso do verbo "desmesurar". A partir daí, surge um jogo de escalas entre o macro e o micro, no qual os olhos são levados a se deslocar do grão de areia à magnitude dos templos e pirâmides aos quais a observação / descrição da concha nos leva numa comparação que modifica completamente a visão recorrente que dela poderíamos ter. O mesmo parece se dar com o uso das metáforas que, ao suprimir o uso do "como", explora ao máximo essa aproximação entre a concha e a "tiara bastarda". Certamente que tanto em Ponge quanto em Perec, não se trata de uma abordagem meramente subjetiva, pois que, como vimos, há na poética dos dois autores uma preocupação objetiva com a coisa. Porém, a economia descritiva utilizada por ambos aponta o tempo inteiro para esse "acento" em que o que é descrito parece resistir à pureza de um puro em si.

\section{Os jogos do dentro e fora}

No capítulo "La place du sujet lyrique" do livro Vers une littérature de l'épuisement, Dominique Rabaté fala do texto como "traço", sugerindo uma "leitura sintomática" de certo tipo de narrativa que "quer descrever e efetuar o nascimento do sujeito do discurso." (RABATÉ, 2004, p.63) Ao falar de um "sujeito do discurso", Rabaté marca de forma clara os limites entre este pensamento e uma fenomenologia estrita que permitiria pensar no funcionamento da narrativa como uma espécie de espelho estável, um duplo "acabado" que coincidiria completamente com o "sujeito da escritura". ${ }^{4}$ Afastados os riscos dessa coincidência nos termos de uma leitura "biográfica", podemos pensar nessas escrituras como instauração do trabalho de descrição e engendramento do sujeito. É por essa via que devemos analisar a questão/comentário que Perec propõe a seu leitor no artigo "Aproximações do quê?": "[c]omo falar dessas 'coisas comuns', ou melhor, como cercá-las, trazê-las para fora, arrancá-las da casca onde estão presas, como dar-lhes um sentido, uma língua: que elas falem enfim do que é, do que somos." (PEREC, 210, p.179) No final dessa passagem, Perec estabelece um paralelo entre as coisas e os homens por intermédio da escrita, pois dar uma língua às coisas seria também falar "do que somos." Se pensarmos nas relações de Perec com a revista Cause commune por meio de seus dois editores, Paul Virilio e Jean Duvignaud, fica claro que há uma visada antropológica nesse comentário. Entretanto, a escritura perecquiana, ao referir-se ao Homem em sentido lato, não pode ser pensada sem esse desejo de autoconhecimento que o autor chamava de "autobiográfico". 
O coletivo é menos uma abstração servindo para falar da humanidade em geral que o estabelecimento de pontos de referência a partir dos quais o sujeito pode existir.

Se "dar uma língua às coisas" o permitiria existir ao mesmo tempo em que falasse do Homem, é esse mesmo processo, como vimos, que nos permite apreender seu acento. Cada descrição desembocaria em um sistema de nomeação marcado pelo encontro do olhante e do olhado numa dinâmica em que o "eu" não poderia apreender-se sem levar em conta o movimento daquilo que o observa. A escritura seria, então, a experiência desse jogo de olhares sob a forma do "traço", o que remete ao mesmo tempo ao mundo e ao sujeito que o descreve sem que se possa separá-los. E quanto mais os escritores desestabilizam as economias descritivas usuais, mais esse aspecto "sintomático" das imagens funciona como sintoma de sua "intromissão".

Certamente que essa dinâmica não ocorre sem ambiguidade na obra de Ponge, o que podemos atestar ao ler em um de seus escritos: "jamais referência ao homem." (PONGE, 1961, p.255) Assim como Perec, Ponge também intenciona "fazer falar as coisas" (PONGE, 2000, p.39), e da mesma forma que o autor de A Vida modo de usar, tal procedimento não é um afastar-se do homem, mas o meio encontrado para ir ao seu encontro. $\mathrm{O}$ próprio poeta procura desfazer um possível mal-entendido ao afirmar que,

o homem não é meu assunto direto, ao contrário, mas eu sei também que quanto mais intensamente procurar a resistência ao homem, a resistência que seu claro pensamento encontra, mais chances terei de encontrar o homem, não de reencontrá-lo, de encontra-lo pela primeira vez, de encontrar o homem que ainda não somos, o homem com mil qualidades novas, inauditas. (PONGE, 1997, p.121)

E como ele assinala no poema "Les façons du regard", "[e] xiste uma ocupação a cada instante reservada ao homem: é o olhar-de-tal-maneira-que-o-falemos, o comentário daquilo que o cerca e de seu próprio estado no meio daquilo que o cerca." (PONGE, 2006, p.120) Assim como em Perec, em Ponge as coisas não são um atestado do desaparecimento do homem, mas o meio através do qual o homem pode dar testemunho de sua presença.

No artigo "Da subjetividade na linguagem", Benveniste afirma que "[é] na linguagem e pela linguagem que o homem se constitui como sujeito; porque só a linguagem fundamenta na realidade, na sua realidade que é a do ser, o conceito de 'ego'." (BENVENISTE, v.1, 1995, p.286). Se este comentário tem a virtude de estabelecer as relações entre subjetividade e linguagem, todavia, ele não parece levar em conta o conjunto de problemas de que tratamos. Ao basear seu argumento sobre o conceito de ego, o linguista confere uma estabilidade ao sujeito, capaz assim de se referenciar por meio de uma economia enunciativa que ele chega a descrever em "A linguagem e a experiência humana", publicado 
5 É na famosa "Carta a Georges Izambard" que o poeta profere aquela que seria uma das formulações mais paradigmáticas da crise da subjetividade que perpassará todo o século XX: "[e]stá errado dizer: Eu penso. Deveríamos dizer: Pensam-me." (RIMBAUD, 2006, p.155) Em forma de um arremate avassalador, Rimbaud conclui: "EU é um outro." (idem, ibidem). no segundo volume dos Problemas de linguística geral. Nesse texto, Benveniste retoma a questão ao afirmar que "[t]odo homem se coloca em sua individualidade enquanto eu por oposição a tu e ele." (BENVENISTE, v.2, 1995, p.68). Esse "por oposição a" indica um jogo de antagonismos a partir do qual o sujeito poderia apreender-se enquanto uma individualidade no seio do mundo, numa operação de auto-reflexividade que asseguraria o lugar desse "ego", como visto há pouco. Porém, se continuamos a seguir as reflexões de Ponge citadas mais acima, essa descrição não se mostra de toda correta, ao menos no que tange a obra dos escritores aqui analisados. Assim, para refletirmos sobre as relações entre subjetividade e escrita no processo de criação das imagens na poética de Ponge e Perec, é preciso que reelaboremos esse esquema. A economia descritiva encenada em seus textos parece falar de um encontro que indica um processo de contaminação entre aquele que olha e o olhado, em uma dinâmica que instaura um ir e vir entre sujeito e objeto que impede uma reflexão baseada em uma simples oposição entre "eu" e o "outro".

Benveniste raciocina em termos linguísticos, apoiando-se sobre uma base filosófica que não parece escapar totalmente do paradigma das filosofias do cogito. Retomando um dos textos citados, encontramos a seguinte afirmação: 'é 'ego' que diz ego. Encontramos aí o fundamento da 'subjetividade' que se determina pelo status linguístico da 'pessoa'." (BENVENISTE, v.1, 1995, p.286) Ao desenvolver suas reflexões em termos de uma filosofia da consciência que não leva em conta a constatação feita por Rimbaud em sua carta a Georges Izambard ${ }^{5}$, Benveniste parece chegar a uma conclusão que, como já havíamos dito, não pode dar conta da complexidade do fenômeno abordado. Remetendo o leitor novamente às elaborações teóricas de Rabaté, poderíamos dizer que a literatura de Perec, assim como a de Ponge, é na verdade o local em que esse je torna-se a forma homônima jeu numa tentativa de dar um pouco mais de sentido a esse sujeito que não chega a se apreender enquanto tal em meio à simples enunciação opositiva dos pronomes pessoais.

Tanto em $O$ partido das coisas, quanto em A Vida modo de usar, a figuração dos objetos nunca remete a um puro "em-si" da coisa. Tudo indica que estamos diante de um registro formal em que a escritura aparece como a dialética de um encontro em que olhante e olhado se reúnem na figuração de uma imagem. Esta seria uma espécie de impressão obtida por meio da escritura como resultante de forças entre sujeito, linguagem e coisa, permitindo assim que o escritor se apreenda nessa exterioridade reflexiva. Perec é consciente desse trabalho, como ele nos faz compreender, ao falar da importância de escrever sobre seus próprios objetos:

Mais precisamente, será uma vez mais uma maneira de marcar meu espaço, uma abordagem um pouco oblíqua de minha prática cotidiana, uma maneira de falar de meu trabalho, de 
minha história, de minhas preocupações, um esforço para apreender alguma coisa que pertence a minha experiência, mas não no nível de suas reflexões longínquas, mas no coração de sua emergência. (PEREC, 2003b, p.23)

Apreender sua própria experiência não como anterioridade, mas "no coração de sua emergência". É essa mesma operação que percebemos transposta na narrativa de $A$ Vida modo de usar. Para ficarmos nos exemplos dos porões, vejamos o capítulo XXXIII, "Porões, 1 ", em que o narrador descreve as caves das famílias Altamont e Gratiolet. Por meio de listas inesgotáveis, somos levados a uma escavação obsessiva através dos rastros deixados pelos personagens. Ao apresentar a cave dos Gratiolet, o narrador nos informa: "[v]árias gerações foram empilhando aí refugos que pessoa alguma organizou ou selecionou." (PEREC, 2009, p.2009). E após essa pequena apresentação, somos imersos em uma miríade de objetos: "um porta-casaco de ferro batido"; "o casaco usado por Olivier Gratiolet"; "um velho globo terrestre de papelão"; "pilhas e mais pilhas de jornais e revistas desparelhados"; "Uma caixa de papel transbordante de fotografias amarrotadas"; "conchinhas e caramujos recolhidos por Olivier Gratiolet em Gatseau"; etc. É preciso pensar que Perec não só criava objetos imaginários como, frequentemente, inscrevia nessas listas os de seu uso pessoal ou observados por ele. Questionado por Ewa Pawlikowska quanto à importância dos objetos em $A$ Vida modo de usar, o autor comenta: "[à]s vezes, são objetos que para mim têm um sentido bem preciso. Enfim, objetivamente, que têm um sentido sentimental muito forte. (PEREC, 2003a, v.2, p.211) Assim, nas enumerações descritivas como a que acabamos de ver, em meio aos rastros dos personagens, encontram-se os do próprio escritor. É preciso pensar nessa operação relacionando-a ao outro fragmento, citado pouco antes, em que Perec fala dessa apreensão de uma experiência do sujeito ao exteriorizar-se em uma forma-escritura por meio da descrição de seus objetos.

Mas abandonemos por alguns instantes o campo restrito da literatura. Ao comentar seu trabalho, o artista plástico Alberto Giacometti dá a seguinte explicação: “(...) uma escultura não me interessa verdadeiramente senão na medida em que ela é, para mim, o meio de retornar para mim a visão que tenho do mundo exterior." (GIACOMETTI, 1993, p. 16) Porém, essa visão atribuída a um sujeito não existiria antes da forma-escultura e é ao compô-la que o artista pode, assim como Ponge e Perec, tentar apreender alguma coisa de si. Algo que Giorgio Agamben nos diz em seu texto "O autor como gesto", ao afirmar que provavelmente "só depois de ter escrito - ou enquanto escrevia - a poesia, aquele pensamento e aquele sentimento se lhe tornaram reais, precisos e indesapropriáveis em cada detalhe (...)." (AGAMBEN, 2007, p.62)

Ainda que no início de sua carreira Perec não tenha insistido tanto nessa temática, é, contudo, nos primeiros artigos que 
escreveu, produzidos para o projeto de uma revista chamada $L G$, que vamos encontrar seus primeiros indícios. Em um desses textos, lemos que "[a] literatura sendo, antes de tudo, uma atividade individual (...), ela é em primeiro lugar o registro de uma experiência pessoal, e escrever, é escrever para se conhecer ou se compreender." (PEREC, 1992, p.53). E à medida que Perec desenvolve sua obra ficcional, sua reflexão meta-literária encaminha-se cada vez nessa direção, o que pode ser verificado pelo aumento desse gênero de questionamentos nos dois volumes que reúnem suas entrevistas e conferências ${ }^{6}$.

Uma vez mais, esse tipo de reflexão parece favorecer a aproximação entre Ponge e Perec. Ao falar de seu trabalho poético, Ponge explica que "a variedade das coisas é, em realidade, o que me constrói." (PONGE, 1996, p.12). Ligando essa afirmação do poeta àquela em que ele fala de seu acento, percebemos essa relação direta entre este e a noção de construção. Na verdade, trata-se de uma dupla construção, pois o poeta é constituído pelas coisas, mas à condição de expô-las através de seu acento, estabelecendo essas idas e vindas entre sujeito e escritura. As coisas não esperam passivamente que o escritor as descreva; elas o incitam também à ação, como nos confessa Ponge em um de seus Proêmes de nome "Testemunho": "[u]m corpo foi colocado no mundo e mantido durante trinta e cinco anos dos quais ignoro quase tudo, presente sem trégua a 'desejar' um pensamento para o qual meu dever seria de conduzi-lo à vida." (PONGE, 1998, p.120) É esse olhar que o narrador de A Vida modo de usar oferece ao leitor do romance, mas que podemos encontrar em sua forma mais "bruta" no livro Tentative d'épuisement d'un lieu parisien, publicado anos antes. Descrevendo o movimento da banalidade cotidiana, Perec anota: “[u] $\mathrm{m}$ raio de sol. Vento. Bem ao fundo, um carro amarelo. Um carro de polícia. Alguns carros. Um carro Atlas Reiser. Um homem cujo braço esquerdo está preso num gesso. (PEREC, 2008, p.49)

Michel Collot, em seu livro Francis Ponge : entre mots et choses, ao falar desse trabalho poético, explica que a "'viagem na espessura das coisas' (...) não é assim uma excursão pitoresca em um mundo exótico, mas uma exploração de si." (COLLOT, 1991, p.192). Apesar da diferença entre os trabalhos dos dois autores, parece-me que é nessa mesma "exploração de si" que devemos pensar ao lermos uma obra com A Vida modo de usar, romance em que o infra-ordinário perecquiano desempenha um papel de extrema importância. Mas não abandonemos a trilha aberta por Collot. Em um texto intitulado "O sujeito lírico fora de si", ele volta a abordar a questão da subjetividade literária, alargando assim a problemática para fora dos limites da obra de Ponge. Collot apresenta a tese de que no que tange ao sujeito lírico moderno, "[e]le não pode, então, reaver sua verdade mais íntima pelas vias da reflexão e da introspecção. É fora de si que ele a pode encontrar."

Ver bibliografia. (COLLOT, 2004, p. 167) A despeito de ter escrito poemas, certa- 
mente que não podemos pensar na obra de Perec como sendo a de um poeta. Todavia, a afirmação de Collot não parece em dissonância com sua poética. Além disso, tentar operar a partir de uma divisão por demais estreita de gêneros pareceria, no caso das literaturas em questão, um equívoco teórico. Na escritura de Perec, a imagem criada é, de certa maneira, o flagrante delito cometido pelo escritor diante de seus próprios olhos, único meio do qual dispõe o sujeito para captar-se em plena emergência de seu pensamento.

\section{A assinatura do homem por vir}

O desenvolvimento dessa questão vai desembocar na impossibilidade de apreensão de um "espírito" anterior ao ato de nomeação. O diálogo entre as reflexões de Rabaté, Collot ou Agamben com as poéticas descritivas de Ponge e Perec aponta para esse processo de subjetivação em que o sujeito não se apreenderia senão no instante mesmo em que interior e exterior se encontram nessa matéria chamada texto. É o que faz da obra o ponto de emergência dessa experiência, mais do que a marca de uma impressão sobre o espírito do artista. As imagens fabricadas pelo escritor seriam o resultado dessa dialética do olhar, o que o permite ver-se naquilo que ele [in]forma.

Em 1972, Perec publicou um artigo no primeiro número da revista Cause commune no qual essas questões a respeito de escrita e subjetividade emergem de maneira bastante explícita. Trata-se de um auto-retrato intitulado "Les gnocchis d'automne ou quelques questions me concernant". Em sua biografia sobre o autor, Bellos explica que esse título inusitado remete ao antigo preceito grego pronunciado por Sócrates, de acordo com Platão: “ (...) gnoti se auton, 'conheça-te a si mesmo' (...)”(BELLOS, 1994, p.513). Em certo momento de seu artigo, Perec faz o comentário que se segue:

Meu problema seria antes o de chegar, não digo à verdade (porque eu a conheceria melhor que quem quer que seja e, consequentemente, com direito eu tomaria a palavra?), também não digo à validade (isso é um problema entre mim e as palavras), mas antes à sinceridade. Não é uma questão moral, mas uma questão de prática. (PEREC, 1990a, p.69)

E alguns parágrafos abaixo da passagem acima citada, o escritor confessa: "[e]u esperava, para ser, que os outros me designassem, me identificassem, me reconhecessem. Mas por que através da escritura?" (idem, p.74) Ao longo desse texto, pululam questões dessa ordem, até que o escritor chegue, em uma espécie de conclusão, a dizer que após ter utilizado a escrita para se esconder, é chegado o momento de se procurar. Escrito antes da publicação de Wou a memória de infância, talvez seu livro mais declaradamente autobiográfico, curioso constatar que o surgimento desse projeto aponta para uma dupla impossibilidade: a de se 
chegar ao mesmo tempo à "verdade" e à "validade". O escritor escolhe, então, a sinceridade, não sem precisar que se trata menos de uma "moral" que de uma "prática". Essa sinceridade seria a própria escritura, na medida em que essa prática pressupõe uma maneira de escrever, ou seja, uma poética. Dessa forma, a pergunta "porque através da escritura?" tem valor menos como questão que por seu caráter de constatação: é pela escritura. É como escritor que Perec pode buscar uma aproximação com essa experiência de autoconhecimento, numa tentativa de montagem de um auto-retrato. E o afastamento, logo de saída, da verdade e da validade como categorias desse empreendimento apontaria para a intuição de que mais que descoberta de uma verdade fixada como anterioridade a ser desvelada, a importância situa-se na própria escritura, prática por meio da qual será possível ser identificado, não só pelos outros, mas como por si mesmo.

Tanto em Perec quanto em Ponge, o cotejo de suas reflexões metaliterárias com sua produção propriamente literária - fronteira que em ambos não prima pela clareza - leva-nos de encontro à problemática colocada por Derrida concernente à presença. Em sua comunicação "Assinatura Acontecimento Contexto", ao questionar a centralidade da consciência e da intencionalidade no ato ilocutório tal como analisado por Austin, Derrida critica o raciocínio calcado na ideia de uma "consciência livre e presente na totalidade da operação, de querer-dizer absolutamente pleno e senhor de si (....)" (DERRIDA, 1991, p.365) Depreende-se dessa dinâmica o deslocamento do valor usual do conceito de autor, não mais anterioridade garantidora do sentido do escrito, remetendo-nos a um franco diálogo com as reflexões de Agamben. Retomando a introdução de $O$ partido das coisas lemos estas palavras: "[p]or muito tempo exprobrei as palavras por me enganarem. Atualmente, lhes sou reconhecido: elas me enganam, e, portanto, me descobrem." (PONGE, 2000, p.39) Essa descoberta, é preciso lembrar, não diz respeito àquilo que foi, mas àquilo que virá a ser.

Mesmo se a obra de Perec parece menos "programática" que a de Ponge no que tange a sua relação com as coisas, podemos observar diversos comentários proferidos ao longo de sua carreira durante diversas entrevistas. Nestes, o escritor toma uma posição clara no que concerne ao lugar do sujeito naquilo que ele produz, pois para Perec o real é antes de tudo uma produção devida à interação desse mesmo sujeito com o mundo através da linguagem. Sendo assim, a única possibilidade de acesso a esse real seria pelo viés da escritura. Isso não consistiria em colocar o mundo em posição de passividade em relação a uma anterioridade auto-reflexiva do sujeito da escritura. Durante uma entrevista a Bernard Milluy, Perec faz a seguinte afirmação: “[a]credito que a escritura seja uma espécie de feixe luminoso que poderia, e deve mesmo, esclarecer a totalidade de minha experiência."(PEREC, 2003a, v.2, p.305) Ou seja, para o escritor a obra tem esse valor 
de experimentação de um sujeito em busca de si, um sujeito que tenta compreender "a totalidade da minha experiência" a partir da prática da linguagem escrita.

As poéticas de Ponge e Perec, ao falar dessa "evidência" da banalidade cotidiana, dão testemunho dessa dinâmica em que o sujeito vai ao encontro ao mundo como forma de construir referências para aí apreender-se. É o que Perec chama de uma antropologia endotique em oposição a exotique: “(...) aquela que falará de nós, que irá procurar em nós aquilo que durante muito tempo pilhamos dos outros." (idem, p.11-12) Dito de outra forma, mais o autor mergulha nesse mundo que é o nosso, esse que de tão evidente não mais o vemos, mais o sujeito vai ao encontro de si. Aproximando novamente essas reflexões daquelas de Collot, "[o] sujeito lírico virá a ser 'si mesmo' apenas através 'da forma realizada do poema', que encarna sua emoção em uma matéria que é ao mesmo tempo do mundo e de palavras (....)" (COLLOT, 2004, p.167).

É preciso, porém, realizar uma crítica visando a problematização da posição das poéticas desses autores como "vir a ser 'si mesmo"' de uma presença absoluta a si. Em Pratiques d'écriture ou l'inachèvement perpétuel, Ponge aponta para o inacabamento perpétuo constituinte de sua poética: "[s]obre as coisas mais simples, tudo me parece restar por dizer (...)." (PONGE, 1984, p.65) Numa passagem que podemos colocar em paralelo com essa, Perec, ao falar de seu trabalho, sentencia: " $[\mathrm{o}]$ discurso jamais cessará. E a verdade nunca será atingida. Finalmente, sempre haverá uma abertura na direção de qualquer coisa a dizer (...)." (PEREC, 2003a, v.2, p.79) Operando sobre o signo do interminável, a literatura não pode dar senão a imagem vacilante do sujeito, num constante retardamento desse "vir a ser 'si mesmo".'

No capítulo IV, “Marquiseaux, 1", o narrador de A Vida modo de usar fala de um livro aberto sobre a mesa, "do qual se podem ler o título e o subtítulo - A sinfonia inacabada, romance - mas cujo nome do autor permanece oculto (...)." (PEREC, 2009, p.28) Livro dentro do livro, essa mise en abyme, embora tímida, remete ao inacabamento ao qual o nome do autor está condenado. Apesar das diferenças - pois que elas existem -, nas poéticas descritivas de Ponge e Perec o nome do autor encontra aqui sua formulação paradigmática, apontando para esse duplo movimento de um apreender-se na obra sob a forma de uma impossibilidade de uma total presença a si. Se a sinfonia é inacabada, como poderá o autor encontrar sua plena formulação na forma de uma assinatura final? "O nome do autor permanece oculto", pois sua verdadeira assinatura não remete senão àquele que ainda virá. 


\begin{abstract}
This work intends to analyze the process of subjectification through the writing in the descriptive poetics of booth Francis Ponge and Georges Perec. Describing the banality of the world around them, Ponge and Perec establish a relation between things, man, and language through a narrative economy in which the more the subject describes his external space the more he approaches a search of himself.
\end{abstract}

Keywords: Francis Ponge; Georges Perec; subjetivação; poesia francesa contemporânea.

\title{
REFERÊNCIAS
}

AGAMBEN, Giorgio. "L'auteur comme geste". Profanations. Trad. :Martin Rueff. Paris : Éditions Payot \& Rivages, 2006, p.77-93. ANDRADE, Carlos Drummond de. A Rosa do Povo. Rio de Janeiro: Record, 1984.

CERTEAU, Michel de. L'écriture de l'histoire. Paris : Gallimard, 2002. DERRIDA, Jacques. "Assinatura Acontecimento Contexto". In: Margens da Filosofia. Trad.: Joaquim Torres Costa, Antônio M. Magalhães. Campinas: Papirus, 1991, p.349-373.

BENVENISTE, Émile. Problemas de Lingüística Geral I. Trad.: Maria da Glória Novak e Maria Luiza Neri. Campinas: Pontes, $4{ }^{\text {a }}$ ed , 1995.

Problemas de língüística geral II. Trad.: Eduardo Guimarães. São Paulo: Pontes, 1989.

COLLOT, Michel. Francis Ponge: entre les mots et les choses. Champ Vallon, 1991

. "O sujeito lírico fora de si". Tradução de Alberto Pucheu. In: Revista Terceira Margem, Rio de Janeiro: 7 Letras, ano 8, n. 11, 2004, p. 165-177

DÉBORD, Guy. La Société du Spetacle. Paris: Gallimard, coll. Folio Essais, 1992.

DIDI-HUBERMAN. Devant l'image. Paris : Les Éditions de Minuit, 1990.

GIACOMETTI, Alberto: Je ne sais pas ce que je vois qu'en travaillant. Paris : L'Echoppe, 1993.

PEREC, Georges. Wou le souvenir d'enfance. Paris : Danoël, 1975. . A Vida modo de usar. Trad.: Ivo Barroso. São Paulo : Companhia das Letras, . siècle, 1989. L'infra-ordinaire. Paris : Seuil, coll. Librairie du XX 
As Coisas : uma história dos anos sessenta. São Paulo : Companhia das Letras, 2012.

. L.G: une aventure des années soixante. Paris : Seuil, coll. Librairie du XXe siècle 1992. . Espèces d'espaces. Paris: Galilée, 2000.

. Entretiens et Conférences I et II. Paris : Joseph K., 2003a. . Penser / Classer. Paris: Hachette, 2003b.

. Tentative d'épuisement d'un lieu parisien. Paris : Christian Bourgois éditeur, 2008.

. "Aproximações do quê ?". In : Alea : estudos neolatinos. Trad.: Rodrigo Silva Ielpo. Rio de Janeiro: 7 Letras, v.12, no1, 2010, p.177-180.

PONGE, Francis. O partido das coisas. Trad. de Adalberto Müller, Carlos Loria, Ignacio Antonio Reis, Júlio Castañon Rodrigues, Michel Peterson. São Paulo: Iluminuras, 2000.

- Le parti pris des choses. Paris : Gallimard, 1998.

Hermann, 1984.

. Pratiques d'écriture ou l'inachèvement perpétuel. Paris : . Le Grand Recueil. Paris : Gallimard, 1961.

Imago, 1997.

. Métodos. Trad. : Leda Tenório da Motta. Rio de Janeiro :

RABATÉ, Dominique. «Énonciation poétique, énonciation lyrique ». In : Figures du sujet lyrique. Paris : PUF, coll. Perspectives littéraires, 1996, p.65-79

Vers une littérature de l'épuisement. Paris : Corti, 2004.

RIMBAUD, Arthur. “Carta a Georges Izambard”. In : Alea : estudos neolatinos. Trad.: Marcelo Jacques. Rio de Janeiro: 7 Letras, v.8, n¹, 2006, p.154-156. 